\title{
Штрихи к лингвистическому портрету А. М. Пешковского в контексте научной полемики его времени
}

\author{
о. В. НИКИТИН \\ Кафедра истории русского языка и общего языкознания, Московский государственный \\ областной университет, ул. Веры Волошиной, д. 24, RU-141014 Мытищи \\ E-mail: olnikitin@yandex.ru
}

(Received: 1 March 2019; accepted: 19 May 2019)

\section{1. Вступление}

Имя и труды замечательного ученого-лингвиста и педагога профессора Александра Матвеевича Пешковского (1878-1933) широко известны современной науке. Они служили не одному поколению исследователей-русистов и школьных учителей образцом вдохновенной мысли, строгости в подходе к анализу языковых явлений, привлекали широтой поднятых проблем, большими личными познаниями в области преподавания русского языка, синтаксиса, стилистики, поэтики.

За последние годы уже несколько раз переиздавалась ставшая классическим учебником для многих поколений книга А. М. Пешковского «Русский синтаксис в научном освещении» (см. литературу: Пешковский 2007: 796). Получившая заслуженное признание при жизни ученого, она и теперь звучит актуально. Между тем в его «лингвистическом багаже» есть уникальные образцы научных исследований разного типа: многочисленные статьи по современному языкознанию и методике преподавания русского языка, глубокие, оригинальные, не потерявшие своего значения словарные статьи 1920-х гг. по лингвистике, работы по языку художественной литературы, рецензии и многое другое. Все они, к сожалению, оказались забытыми, несмотря на содержащиеся в них ценные идеи и наблюдения, и были переизданы нами в объемном томе лишь относительно недавно (Пешковский 2007).

Стоит заметить, что, кроме бесспорных научных и лингводидактических достоинств произведений А. М. Пешковского, есть и другие (редкие ныне) особенности его трудов. Это - доступность изложения, лаконичность формулировок, очень удачный подбор иллюстративного материала, любовь и внимание к читателю и действительно русский язык, не испорченный неумеренным использованием подчас неэффективной терминологии, засоряющей языковой вкус, обедняющей строй и гармонию родной речи. В этом смысле 
А. М. Пешковский - непревзойденный педагог и, как это ни парадоксально звучит, традиционалист-новатор.

\section{2. Лингвист-экспериментатор: штрихи к портрету ученого}

Об Александре Матвеевиче Пешковском - незаурядном филологе и педагоге - в последнее время написано немало работ (АПРЕсян 2001, КлоБуков 2001, Никитин 2006, Никитин 2017а, Никитин 2017b, Никитин 2017с и др.), а его методические опыты, осуществленные на заре «лингвистического века», уже давно стали частью истории - филологической традицией.

Опыт А. М. Пешковского бесценен. Его наследие, обрастая с годами порой причудливыми методиками, «новоязом» и всякого рода инновациями, сделанными на потребу времени, не потерялось - оно еще более утвердило в науке имя А. М. Пешковского, приковало к нему внимание современников. Одни видели в нем последовательного «фортунатовца», другие не разделяли его лингвистических взглядов, третьи путем надуманных социологизаторских лозунгов впутывали его светлое имя в эшелон «контрабандистов». Ученый всю сознательную жизнь находился под перекрестным огнем критики. Он не принадлежал только XIX веку, когда происходило становление его личности. И к XX столетию с его бесконечными шатаниями, поисками и идеологическими штампами он нашел свой подход, выделился из вереницы канувших в лету педагогов и методистов. Его имя и научные открытия вызывали восторженные отклики и заслуженное уважение и в то же время были порицаемы. Не избежал он и обвинений в свой адрес, которые тянулись много позднее его земного пути.

В жизни и трудах ученого есть немало общего: он одинаково долго, не без личных переживаний и раздумий, шел к своей цели в науке и весь жизненный опыт пытался реализовать в педагогическом творчестве; он был верен традициям Московской школы, и человеческая практика подсказывала ему, как следует жить в науке, каких критериев придерживаться, чему и кому служить.

А. М. Пешковского нельзя назвать кабинетным ученым. Вся его жизнь и деятельность были направлены на общественное служение и ориентировались, вопреки натянутым «концепциям» некоторых современников и последователей, на изучение психологии восприятия слова, на создание научной базы языковых знаний в процессе обучения. Вот поэтому в работах ученого мы не найдем пустых схоластических приемов или самовлюбленного позирования. Его теорию (а вернее сказать, теории) рождал сознательный эксперимент, который был неотъемлемой частью филологической и человеческой жизни А. М. Пешковского (см. АлПАтов 2001: 232, БудАГов 1988: 153-176). Он одинаково хорошо владел строгим лингвистическим мастерством построения теории грамматики и так же тонко чувствовал совсем иную грань языкового творчества - ритм стиха и ритм прозы. 
Жизненность трудов А. М. Пешковского состоит в том, что они не стали отражением внешних наслоений и не находились под печатью идеологического или же личностного гнета. Его взгляды, в чем-то устаревшие, но тем самым показывающие уязвимость любой, даже совершенной гипотезы, обсуждаются и сейчас. Он сумел обобщить громадный опыт школьной и вузовской практики, заставляя нас не упрощать и не искажать факты, не жить ложными представлениями о развитии языка. Это качество А. М. Пешковского, присутствующее во всех его работах, передается и читателю, который, может быть, впервые начинает задумываться над словом не публично, а «про себя». Оживить образ слова, сохранить его для потомков, помочь им углубить знания о языке - этим высоким служением была наполнена научная деятельность А. М. Пешковского. Идеи, которые излагал ученый, выходят за пределы его времени и переступили порог XXI века, а созданная им система занятий со школьниками «от звука к значению», «от значения к форме» оказалась востребованной и в наши дни.

\section{3. Поиски лингвистического «эго»}

Уходили, один за другим, виднейшие отечественные филологи-слависты и лингвисты - Ф. Ф. Фортунатов, Ф. Е. Корш, А. А. Шахматов, которые своим авторитетом и титанической деятельностью готовили новые силы, вели вперед, какой бы областью они ни занимались - диалектологией, современным или восточным языкознанием, компаративистикой. Именно тогда, на рубеже XIX-XX веков, накануне больших перемен, и зародилось новое (хотя по сути своей - классическое и строго научное) направление, ставившее своей задачей в том числе и поднятие авторитета русской науки в целом путем обращения к богатейшему опыту классиков и живой исследовательско-экспедиционной работы в разных направлениях филологии, поставленной уже не на разрозненные, хаотично движущиеся «эксперименты», а на строго организованную и обоснованную систему, приоритетом которой была наука конкретных данных (А. М. Селищев) - лингвистика. Роль Московской лингвистической школы и кружка молодых ученых в этом, несомненно, велика. Из нее вышли крупнейшие ученые, сформировавшие костяк Московской лингвистической школы. Но в то же время она была и центром филологического эксперимента, где опробовались многие индивидуальные методики и решались актуальные задачи новой науки.

Первый труд А. М. Пешковского «Русский синтаксис в научном освещении» стал заметным явлением в языкознании того времени и вызвал широкий резонанс в филологической печати (Пешковский 1914). Педагог-практик заявил о себе ярким, цельным, методологически продуманным исследованием, предназначенным «для самообразования и школы». Книга была удостоена премии Академии наук в 1915 г. Как выпускник Московского университета А. М. Пешковский хорошо усвоил идеи фортунатовской школы. 
В предисловии к первому изданию он писал: «Научным фундаментом книги послужили прежде всего университетские курсы проф. Ф. Ф. Фортунатова и В. К. Поржезинского» (цит. по: ПЕшковский 1956: 7). Он также хорошо знал и работы европейских ученых: Ф. Миклошича, Г. Пауля и Б. Дельбрюка. Вместе с тем ученый не отказывался от традиции, заложенной трудами А. А. Потебни и Д. Н. Овсянико-Куликовского, но развивал их взгляды по-своему.

Д. Н. Ушаков в небольшой рецензии на первые работы А. М. Пешковского прямо говорил об истоках лингвистических воззрений автора, не противопоставляя их, а, наоборот, раздвигая диапазон языковедческих школ, показывая преемственность в формировании научной позиции ученого:

Автор как ученый принадлежит к Московской лингвистической школе, т. е. школе профессора и академика Ф. Фортунатова, недавно умершего, но успевшего ознакомиться с этой книгой и высказаться о ней с большой похвалой. На идеях Фортунатова и основана главным образом система г. Пешковского; кроме того, на него повлияли труды Потебни и Овсянико-Куликовского. Естественно прежде всего поставить вопрос об отношении нового синтаксиса к труду этого последнего ученого. Не вдаваясь в частности, скажем, что в деле постановки вопроса о реформе преподавания синтаксиса русская школа более всего обязана Д. Н. Овсянико-Куликовскому; талантливым освещением многих синтаксических явлений он немало сделал также и для разрешения этого вопроса, и в главную заслугу ему должно поставить все то, что́ он сделал на пути разрушения логической точки зрения в синтаксисе; но истинно-грамматического, или, - что то же, - истинно-лингвистического облика в труде его русский синтаксис все-таки не получил. В этом отношении синтаксис г. Пешковского-крупный шаг вперед (УшАКОВ 1915: 6).

Еще один фрагмент справедливо выделил Д. Н. Ушаков как новаторство А. М. Пешковского:

Отметим у г. Пешковского как новость для подобных общих трудов по синтаксису обращение внимания на интонацию и ритм речи как внешние показатели известных синтаксических оттенков (УШАКов 1915: 6).

Именно это свойство лингвистического темперамента ученого и в других его работах будет неизменно присутствовать как одно из основных качеств речевой деятельности, живого слова, на которое всегда ориентировался А. М. Пешковский. Любопытно в связи с этим заметить, что Д. Н. ОвсяникоКуликовский очень положительно отнесся к «Русскому синтаксису...» и писал А. М. Пешковскому в 1915 г.: «Вашу книгу читаю, и она все больше мне нравится» (ОР ИРЛИ. Р. ІІІ. Оп. 1. Ед. хр. № 1560. Л. 1).

Мы не будем останавливаться на обзоре других откликов на первое издание «Русского синтаксиса...», но скажем, что эта книга вызвала «переполох» в лингвистике: шквал рецензий лингвистов и методистов просто захлестнул филологическое пространство того времени (некоторые из них работы Е. Ф. Будде, Л. А. Булаховского, Е. К. Тимченко- мы републиковали 
в кн.: ПЕшковский 2007). Такова была реакция на свежий языковедческий эксперимент А. М. Пешковского.

«Русский синтаксис...» появился в противоречивое время и уже самим фактом издания нес на себе отпечаток идейных столкновений прошлого и настоящего. Их характер хорошо выразил Ю. Д. Апресян во вступительной статье к восьмому изданию этого труда:

Во-первых, это столкновение школьной и научной грамматики и попытка поднять уровень теоретичности школьной грамматики за счет более строгих определений основных грамматических понятий. Во-вторых, это конфликт между историческим описанием языка - господствующим типом научного описания в ту эпоху - и потребностями сугубо практического преподавания современного языка с целью повышения уровня грамотности говорящих и пишущих на нем людей. В-третьих, это конфликт между психологизмом предшествующей эпохи (А. А. Потебня) и формализмом фортунатовской школы русской лингвистики. В-четвертых, это конфликт между требованием марксистской идеологизации всех областей научного знания, во всяком случае на уровне обязательных к исполнению фразеологических штампов, и эмпирическими данными конкретной науки. В-пятых, это конфликт между усиливавшимся давлением марризма и здравым смыслом (АПРЕСян 2001: III).

В 1914 г. выходит еще один известный труд - «Школьная и научная грамматика. Опыт применения научно-грамматических принципов к школьной практике». Задача этой работы состояла в нормализации преподавания грамматики в школе и распространении научных знаний о языке среди широких масс образованного общества. В нем автор четко обозначает «противоречия между школьной и научной грамматикой». Первая, по мнению А. М. Пешковского, «не только школьна, но и ненаучна» (цит. по: Пешковский 1918: 44). В чем же это выразилось? Ученый утверждал:

1) «в школьной грамматике отсутствует историческая точка зрения на язык»;

2) «...отсутствует и чисто описательная точка зрения, т. е. стремление правдиво и объективно передать современное состояние языка...»;

3) «при объяснении явлений языка школьная грамматика... руководится устарелой телеологической точкой зрения, т. е. объясняет не причинную связь фактов, а целесообразность их, отвечает не на вопрос „почему“, а на вопрос ,зачем“");

4) «все классификации школьной грамматики (и это ее главный недостаток) логически неправильны, так как нарушают известное логическое правило об „основании деления“, по которому всякое деление производится по одному какому-либо признаку»;

5) «во многих случаях ложность школьно-грамматических сведений объясняется и не методологическими промахами, а только отсталостью, традиционным повторением того, что в науке уже признано неверным» (ПЕшковСКий 1918: 44-53). 


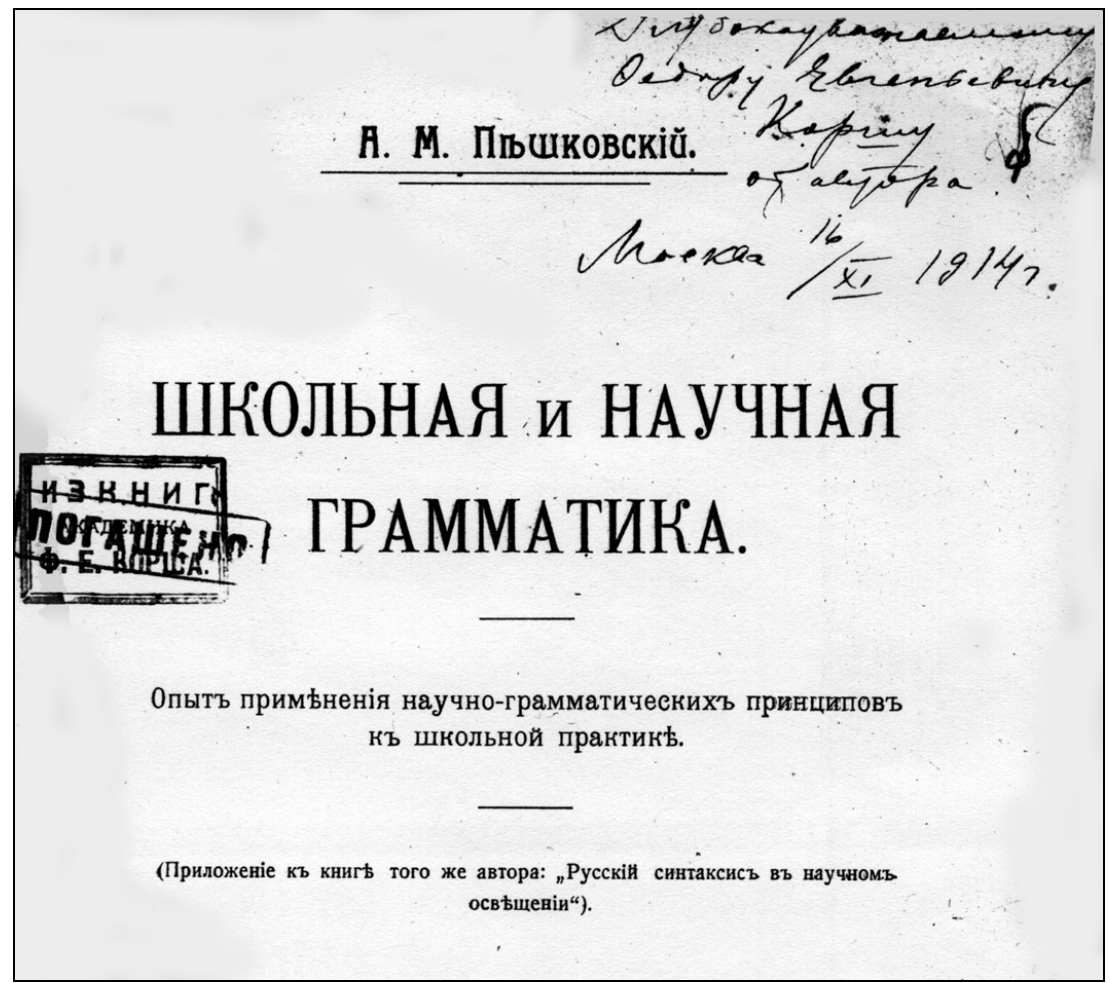

Титульный лист (фрагмент) первого издания книги А. М. Пешковского «Школьная и научная грамматика. Опыт применения научно-грамматических принципов к школьной практике» (Москва, 1914) с дарственной надписью Ф. Е. Коршу

Итак, первые работы ясно определили научные интересы ученого и задачи его педагогической деятельности, которые были неразрывно связаны с практикой преподавания русского языка. Основными он считал такие:

Дать представление возможно более широким слоям читающей публики о языковедении как особой науке...; обнаружить несостоятельность тех мнимых знаний, которые получены читателем в школе и в которые он обычно тем тверже верует, чем менее сознательно он их в свое время воспринимал; отделить грамматическую сущность речи от ее логико-психологического содержания...; наконец, устранить вопиющее смешение науки о языке с практическими применениями ее в области чтения, письма и изучения чужих языков... (Пешковский 1938: 4).

Позднее, уже в 1920-е гг., когда обозначилась «опасность нового кризиса в грамматике» (ШАПиРо 1956: 5) и формальный подход подвергался жесткой критике, книга А. М. Пешковского «Русский синтаксис...» оказалась снова востребованной и обсуждаемой. 
Нужно справедливости ради заметить, что отдельные последователи Фортунатова (так называемые «ультраформалисты»), слишком прямолинейно понимавшие специфику формального подхода к языку и порой доводившие идеи Фортунатова до абсурда, подавали немало поводов для критики. Но главное было иное: стихийное неприятие формально-грамматических построений преподавателями-практиками и методистами русского языка накладывалось на общую ситуацию в советской науке первой половины XX века (Клоьуков 2001: 12).

Указанные обстоятельства отчасти явились толчком к тому, что автор переработал свой труд и усовершенствовал концепцию (см. 3-е и последующие издания). Но и в таком, обновленном, виде книга А. М. Пешковского продолжала будоражить филологическое сознание современников, иногда не понимавших сути замысла ученого и хватавшихся за голые фразы, услужливо приписывая ему то, о чем он никогда не думал.

В Архиве РАН сохранилось замечательное свидетельство соратника А. М. Пешковского Д. Н. Ушакова, немало содействовавшего выходу в свет «Русского синтаксиса...». Он ясно показал те отрицательные тенденции, которые назревали в определенной части общества в 1920-е гг.:

Надо признать, что громадная масса учителей не отдает себе отчета в том, что название «формальный» - название условное, пожалуй, не совсем удачное, подающее повод несведущим думать, будто так называемые «формалисты»- рекомендуют не обращать внимания на значения слов, вообще на смысл, ограничиваясь в изучении языка одной внешней формой. Вот это ходячее недоразумение, основанное на простодушном понимании термина «формальный» в общежитейском смысле «поверхностный, внешний», надо в интересах методической работы рассеять. Надо рассказать учителям, как «формалисты» впервые указали на пренебрежение языком при обучении русскому языку в школе, в частности, что, впрочем, очень важно, устранили существовавшее смешение языка с письмом и показали возможность давать уже в школе, кроме навыков, научные сведения о языке в доступном для детей виде (Архив РАН. Ф. 502. Оп. 1. Ед. хр. № 123. Л. 1).

В русле направлений формализма А. М. Пешковский, например, в 19211923 гг. принимал участие в деятельности Лингвистического общества при Московском университете, заседания которого проходили часто совместно с работой Лингвистической секции Научно-исследовательского института языка и литературы. В указанный период он сделал доклад «О понятии отдельного слова» (см. УШАКОВ 1995: 281).

Все эти события, как мы полагаем, оказали большое влияние и на формирование научной позиции А. М. Пешковского. 1920-е годы - время бурного идеологического строительства, одним из составных частей которого было образование, решавшее практические задачи. Но тогда еще было возможно под вывесками учебных заведений и многочисленных комиссий без нажима сверху свободно обсуждать в том числе и актуальные научные проблемы, имевшие прикладное значение. Отголоски некоторых дискуссий донесли до 
нас и голос А. М. Пешковского. Так, в журнале «Родной язык и литература в трудовой школе» за 1928 г. был помещен отчет работы кафедры языка в Коммунистическом университете имени тов. Сталина, ставившей своей задачей «подготовку квалифицированных партийных работников для советского и зарубежного Востока». В нем отмечалось, что на предметных комиссиях были заслушаны следующие доклады: председателя [так в тексте - O. Н.] кафедры Г. К. Данилова «Основной лингвистический закон по данным Белицкого говора», проф. Е. Д. Поливанова «Понятие эволюции в языке», проф. А. М. Пешковского «Европейская пунктуация и ее недостатки» и др. Здесь дается и краткое изложение всех выступлений:

Проф. Пешковский [...] дал общий обзор европейской пунктуации. Несмотря на частные различия по отдельным языкам, европейская пунктуация представляет, в общем, один тип. Самые знаки пунктуации одни и те же, общий смысл каждого знака одинаков, так что можно говорить об единой европейской пунктуации. Как же определяет европейская пунктуация свои задачи?

Две задачи - фонетико-интонационная и логико-грамматическая [...]. Они принципиально примиримы, но в литературе по вопросам пунктуации нет об'единения этих двух принципов [...].

В самом кодексе европейской пунктуации, во всех правилах, - неточность. Правила пестрят фразами вроде: «иногда ставится запятая», «длинные, краткие» предложения. Тире стало знаком отчаяния. Но если пунктуация - законодательство, то подобные выражения недопустимы. Многопринципность европейской пунктуации на практике оказывается беспринципностью.

Между кодексом и фактической пунктуацией огромная пропасть. Фактически преобладает интонационный момент, теоретически он занимает весьма подчиненное место. Такое положение требует реформы. На первый план необходимо выдвинуть интонационный момент, так как у пишущего всегда желание акустически довести до сознания читающих то, что он пишет. Да и всякий произносит мысленно то, что он пишет. Интонационный принцип должен быть формулирован как психоинтонационный, так как интонация - тонкая вещь, формулировать ее нелегко; это должно происходить на психологической почве. Известные уступки, точно оговоренные, должны быть сделаны и собственнограмматическому принципу (Родной язык 1928: 120-121).

А. М. Пешковский показал себя знатоком европейской лингвистической практики, хорошо понимавшим и чувствовавшим реальную языковую ситуацию.

\section{4. «Пешковщина» на идеологическом фронте науки}

Наступала новая эпоха в лингвистике XX в. - время переворотов в науке, стремительного роста нового, поиска путей совершенствования лингвистических исследований и выхода за пределы сложившихся стереотипов. При всей трагичности тех перемен, которые происходили в общественной жизни страны, ее богатый классическими традициями русской филологии 
потенциал еще в 1920-е - в начале 1930-х гг. не был разрушен до основания. Ученые, взращенные старой академической школой (и в их числе, конечно же, А. М. Пешковский), активно включились в «языковое строительство», стремясь приобщить к гуманистическим ценностям поколение новой России. Изменившиеся условия педагогической деятельности вызвали насущную необходимость написания и издания новых работ по русскому языку для средней и высшей школы, которые в какой-то мере смогли бы заменить «устаревшие» пособия дореволюционного времени. Конечно, при таком перекосе остались невостребованными многие ценные практические руководства признанных классиков науки, педагогов, чьими усилиями слагалась образовательная часть концепции национального развития страны. Так, на долгое время были забыты или отброшены, как «реакционные», «идеалистические» и «ненаучные», труды Ф. И. Буслаева, Я. К. Грота, А. Г. Преображенского... И лишь спустя десятилетия, если не более, мы вновь возвратились к безвременно утраченному наследию... В такой атмосфере жил А. М. Пешковский. И ему стоило немалого мужества отстаивать подлинные традиции русской школы, внедрять живые, а не искусственные эксперименты в обучение, пропагандировать прогрессивные идеи - словом, делать все во благо развития духовной, мыслящей личности.

При том, что А. М. Пешковский был, очевидно, далек от участия в идеологических спорах в лингвистике тех лет и не примыкал ни к одному из возникших направлений и группировок, его труды и особенно «Русский синтаксис...» в течение нескольких десятилетий являлись объектом весьма напористой критики, иногда выходившей за рамки научной дискуссии (БЕлов 1958: 22-24). Таковы, например, крайне претенциозная рецензия Е. Ф. Будде и полемические высказывания Е. Н. Петровой в книге «Грамматика в средней школе» (см. БуддЕ 1914, ПЕтровА 1936). Не избежал ученый и жесткой, часто отрицательной оценки В. В. Виноградова и его обвинений в «гипертрофированности», «эклектизме», «синтаксическом „формализме“» и др. (ВиногРАдов 1938: 69-85). Он посвятил А. М. Пешковскому отдельную главу с характерным заголовком «Эволюция грамматических взглядов проф. А. М. Пешковского и неудавшийся синтез учений Фортунатова, Потебни, Овсяннико-Куликовского, де-Соссюра и Шахматова» (ВиногрАдов 1938: 69). Мы не будем специально останавливаться на оценке В. В. Виноградовым идей А. М. Пешковского (это отдельный большой вопрос), однако отметим, что его критика в основном находилась в плоскости анализа учения А. М. Пешковского о форме слова и о частях речи. В. В. Виноградов писал, что

...двойственность лингвистических точек зрения... непоследовательность классификации, блуждающей на распутье между морфологическими абстракциями фортунатовской системы и потебнианскими функционально-синтаксическими характеристиками, медленно, но упорно преодолевается Пешковским... (ВиноГРАДОВ 1938: 69).

Правда, общий вывод критика звучал очень сурово: 
Синтаксический «формализм» помешал Пешковскому достигнуть синтетического охвата явлений языка. На всем творчестве Пешковского лежит неизгладимая печать фортунатовской концепции. Фортунатовская система, даже в то время, когда Пешковский субъективно переживал свою свободу от ее формалистических стеснений и выступал врагом «морфологизма», продолжала тяготеть над его лингвистической мыслью. Отсюда - эклектизм синтаксической системы Пешковского... Достигнуть синтеза многообразных лингвистических влияний Пешковскому не удалось (ВиногРАдов 1938: 85).

Справедливости ради стоит отметить, что в своем обобщающем грамматическом труде «Русский язык» В. В. Виноградов не раз ссылался на А. М. Пешковского в том числе и с положительной оценкой: «Эту большую книжность краткой формы А. М. Пешковский иллюстрировал очень ярким примером...» (ВиногРАдов 1947: 264); «А. М. Пешковский справедливо подчеркивал...» (ВиногрАдов 1947: 323); «А. М. Пешковский правильно указывал...» (ВИНОГРАДОВ 1947: 349).

Но наиболее остро взгляды А. М. Пешковского и ученых, последовательно отстаивавших традиции Московской и Санкт-Петербургской лингвистических школ и «старой» академической практики вообще, подверглись критике в 1930-е гг., когда была развернута кампания, связанная с участниками группы «Языковедный фронт» (подробнее см. АлпАтов 2004: 95-101). Под одну «буржуазную» идеологию попали ученые, и имевшие отношение к «Языкфронту» (Г. К. Данилов, Т. П. Ломтев, Я. В. Лоя и др.), и не участвовавшие вовсе в политических дрязгах в науке (Л. В. Щерба, Д. Н. Ушаков, А. М. Пешковский, А. В. Миртов и др.).

Самым показательным документом этой «дискуссии» стала книга с характерным для того времени заголовком-лозунгом «Против буржуазной контрабанды в языкознании» (1932). В ней были представлены статьи и доклады учеников и последователей Н. Я. Марра: Ф. П. Филина, А. К. Боровкова, М. П. Чхаидзе и др. И хотя основной мишенью публицистов стали участники «Языкфронта», поток необоснованной клеветы распространился и на «буржуазное газетоведение», и на «обветшалые отрепья индоевропеизма», и на журнал «Русский язык в советской школе». Имя А. М. Пешковского не раз фигурирует в числе «контрабандистов»: его то называют «идеалистом» (см. Золотов 1932: 16) и пытаются связать со взглядами «языкфронтовцев», то (особенно откровенно) приписывают ему «развязное оголтелое разделывание с марксистско-ленинскими установками в вопросах методологии» (ПетровА 1932: 159), обвиняют в «полной дезориентации учительских масс», в «фальсификации и извращении марксизма-ленинизма» (ПетровА 1932: 160). А. М. Пешковский как один из редакторов «Русского языка в советской школе» был подвергнут внушительной «проработке»: журнал назван «органом „индоевропеистской““ формалистической лингвистики», а руководству Наркомпроса высказано предложение «сделать классовый оргвывод по отношению к редакции и авторскому списку журнала», который «используется как рупор „Языкфронта“» (ПЕтровА 1932: 161). Все, что противоречило марксистской 
идеологии, осуждалось и клеймилось. Даже изобрели такой штамп - пешковщзина (!). Вот показательный пример подобного «анализа»:

Полное отсутствие историзма следует отметить в статьях по категориям речи: Боголепов открыто проповедует теорию знаковости, уподобляя слова алгебраическим знакам $=,+,<$ и $>$. Исключительное внимание (прямо исключающее все остальные стороны языка) интонации в деле пунктуации у Лыскова возвращает нас опять в лоно пешковщины [курсив - О. Н.] (ПетРОВА 1932: 161).

Особенно активен по части «разоблачений» в этом сборнике был Ф. П. Филин, опубликовавший три статьи. В одной из них, вторя Н. Я. Марру, он вскрывает «империалистическую сущность индоевропеистики» - «открытого и главного врага»:

Буржуазное языкознание на современном этапе готово воспользоваться и троцкистской клеветой, и механическими «установками» правых. Оно блокируется с любой реакционной теорией. Маскирующаяся индоевропеистика... в настоящее время является особенно опасной. Сюда должен быть направлен особенно сильный огонь, но это, конечно, ни на минуту не должно ослаблять борьбы с открытым индоевропеизмом типа Пешковского, Ушакова и др. (Филин 1932: 30).

Но это было только начало борьбы на идеологическом фронте...

\section{5. «Пороки формалистической школы»}

Развернутая в конце 1920-х - 1930-х гг. марксистскими идеологами в языкознании кампания по дискредитации старой школы - историков языка, славистов, индоевропеистов и формалистов, коснулась и А. М. Пешковского. Так, Е. Н. Петрова, разбирая его методическую систему и в целом традиции фортунатовской школы, заявила, что они «объявили форму монопольным объектом всех исследований по языку. В этом одностороннем подходе к языку и заключается основная ошибка формалистов» (ПетровА 1936: 28). Называя соображения А. М. Пешковского «антинаучными», автор говорит, что «и программа и методика этой системы ничего общего не имеют с теми задачами, которые ставятся советской школе на основе марксистского подхода к языку» (ПетровА 1936: 34). С явным осуждением констатируются основные «установки» ученого, интерпретированные так:

Формализм, отрыв языка от мышления, отрыв формы от содержания, разрыв теории и практики, выведение языковой науки из школы, монополия «исследовательского» метода как целостная система противоречат установке советской школы (ПЕтровА 1936: 35).

Звучит как приговор А. М. Пешковскому! Но и на этом не останавливается автор: ученого необходимо было «припечатать» к разгромленному индоевропеизму: 
По своим лингвистическим взглядам Пешковский принадлежал к индоевропейской школе. Так, в курсе «языкознания» он придерживался концепции славянского праязыка, выделял славянские языки в одну обособленную семью, причисляя к ним и русский язык, говорил о процессе разобщения и расчленения языков, исторические сличения вел в очень узком кругу «родственных» языков и на узких исторических отрезках времени (ПЕтРОВА 1936: 36).

Как итог такого «анализа» методической системы А. М. Пешковского формальное направление объявляется «реакционным» и «буржуазным», но не лишенным оригинальности. Один из уроков, по мнению автора книги, который может извлечь для себя советская школа, состоял в следующем:

Мы должны тоже учесть и богатство аргументации, искусство внешнего оформления и эрудицию формалистов, которые действительно умели убеждать, так что и сейчас, читая того же Пешковского, необходимо напрягать всю бдительность [курсив - О. Н.], чтобы вскрыть положения, его разоблачающие.

И далее:

Вместе с тем мы не можем не отметить и объективно-прогрессивного момента в формалистическом направлении: определенной системы изложения в учебниках и, главное, обостренного и дифференцированного внимания к специфике формы (ПетровА 1936: 42).

Но все же окончательный вердикт был вовсе не утешительный. В духе материалистической идеологии Е. Н. Петрова перечисляет «печальные последствия» влияния формалистов:

1) оно затормозило продвижение в среднюю школу основ науки о языке; 2) оно сосредоточило все усилия учительства на изобретении всяких искусственных приемов для поддержания интереса к формалистической «схоластике»; 3) поставило единственной целью изучения грамматики навыки и тем обескровило как раз работу по навыкам; 4) искусственно задерживало в наших школах, учебниках и книгах чуждую нам идеалистическую формалистическую методологию; 5) делало наш предмет чужеродным телом в общем деле коммунистического воспитания в школе; его терпели, как неизбежное зло, необходимое, чтобы выучить и писать... (ПЕтровА 1936: 42).

Ср. высказывания другого проповедника марксизма Я. В. Лои: «В настоящее время сильнее всего нужно ударить по формалистическому механицизму или механическому формализму московских лингвистов (Петерсон, Ушаков и др.)» (Лоя 1930: 55).

Но и этими оценками не окончились гонения на А. М. Пешковского и его последователей, таких, например, как В. А. Малаховский, которого обвинили в том, что он усугубил «пороки формалистической школы... левацкими извращениями» (ПЕтровА 1936: 43).

Итак, А. М. Пешковский оказался в центре лингвистической (а по сути идеологической) кампании, которая продолжалась, как мы видим, с немень- 
шей остротой и после его смерти. Впрочем, такая борьба на «лингвистическом фронте» велась в те годы со всеми отступниками от генеральной линии партии, кто не вписывался в ее систему (ср. судьбы лингвистов Е. Д. Поливанова, А. М. Селищева и связанные с ними «дискуссии»).

Во второй половине 1940-х гг., после войны, несмотря на некоторую свободу, выразившуюся в том числе и в попытках дать объективную оценку развития теории и методологии языкознания в советский период (см. ЧЕмОДАНОВ 1947, АБАКУмОВ 1947, БАЗилЕВич 1947), «аракчеевский режим» снова взял реванш. В дискуссии 1949 г. досталось и А. М. Пешковскому. Г. П. Сердюченко, один из активных участников борьбы с «космополитизмом» и «шовинизмом» в языкознании тех лет, опубликовал в газете «Культура и жизнь» (30 июня 1949 г.) статью, где говорилось о «безответственном отношении» Министерства просвещения и обвинялся лично министр А. А. Вознесенский за то, что «в учебных планах для курсов повышения квалификации учителейсловесников из списков рекомендуемой литературы не изъяты „Русский язык“ В. В. Виноградова и „Русский синтаксис в научном освещении“ А. М. Пешковского (труд, в 40-е годы уже считавшийся классическим)» (цит. по: АлПАТов 2004: 157).

Такой полярный разброс мнений, жесткая, часто несправедливая полемика, с одной стороны, показывают большую ценность и оригинальность выдвинутых А. М. Пешковским идей, с другой - отражают «методологические пороки» того времени, которому была свойственна «передержка» в понимании наследия недавнего прошлого, а реплики вроде «идеалистический шлак», «контрреволюционная теория о языке» и подобные господствовали в научной печати тех лет. Вместе с тем воззрения А. М. Пешковского вписались в общий характер развития языкознания у нас и на Западе. В. М. Алпатов справедливо подметил: «В первой четверти XX в. в мировой лингвистике появилась некоторая тенденция специально обратиться к проблемам синтаксиса» (АлПАтов 2005: 169). И А. М. Пешковский был одним из первых «навигаторов» (наряду с А. А. Шахматовым, Л. В. Щербой) на пути осмысления и анализа грамматической системы новых языков.

\section{6. Грамматика без стилистики? (Полемика с Волошиновым-Бахтиным)}

Эти же проблемы, но в несколько ином социологическом ключе были подвергнуты обсуждению в работах М. М. Бахтина и его круга исследователей, полемизировавших с «абстрактным объективистом» А. М. Пешковским. Да и вообще стоит заметить, что формальные школы не только в языкознании, но и особенно в литературоведении активно прорабатывались с позиций «марксистской науки». Так, получила широкую известность работа М. М. Бахтина «Формальный метод в литературоведении», где анализировалось историческое значение формального метода, сыгравшего, по мнению автора, «Плодотворную роль» (БАХТин 2000: 348). 
Но данная дискуссия носила уже другой, подчеркнуто корректный, аналитический, научный характер. В этом отношении показательна книга В. Н. Волошинова (1929) «Марксизм и философия языка», авторство которой приписывают М. М. Бахтину (подробнее об этом см. АлпАтов 2005). Кстати, В. Н. Волошинов не раз клеймился марристами; его называли «фальсификатором марксизма-ленинизма в языкознании» (см. Золотов 1932: 12) - и в этом отношении он находился не в лучшем положении, чем А. М. Пешковский.

В третьей ее части «К истории форм высказывания в конструкциях языка» говорится о проблемах передачи чужой речи. Автор пишет, со ссылкой на «Русский синтаксис...», что

исключительный методологический интерес, присущий этим явлениям, до сих пор совершенно не оценен. В этом, на поверхностный взгляд, второстепенном вопросе синтаксиса не умели увидеть проблемы громадной общелингвистической и принципиальной важности (Волошинов 1929: 135).

При анализе «шаблона косвенной речи» против А. М. Пешковского выдвинули такое критическое замечание:

Пешковский совершает типичную для «грамматика» ошибку. Непосредственный, чисто грамматический перевод чужой речи из одного шаблона передачи в другой без соответствующей стилистической переработки его - есть только педагогически скверный и недопустимый метод классных упражнений по грамматике. С живою жизнью шаблонов в языке такое их применение ничего общего не имеет (Волошинов 1929: 150).

Оценивая эксперимент А. М. Пешковского, автор приходит к выводу об «игнорировании им самого смысла косвенной речи», который «заключается в аналитической передаче чужой речи» (Волошинов 1929: 150).

В примере Пешковского восклицание осла: «Изрядно!» не может быть непосредственно введено в косвенную речь:

«Говорит, что изрядно...»

но только:

«Говорит, что это изрядно...»

или даже

«Говорит, что соловей поет изрядно...» (Волошинов 1929: 151).

Поясняя свое видение этого аспекта социологии грамматики, В. Н. Волошинов заключает:

Косвенная речь иначе «слышит» чужое высказывание, активно воспринимает и актуализирует в его передаче иные моменты и оттенки, чем другие шаблоны. Поэтому и невозможен непосредственный, дословный перевод высказывания из других шаблонов в косвенный... Всматриваясь в «эксперимент» Пешковского, мы замечаем, что лексическая окраска таких слов, как «изрядно», «навострился» - не вполне гармонирует с аналитической душой косвенной речи. Эти слова слишком колоритны... Их хочется заменить смысловыми эквивалентами 
(«хорошо», «усовершенствоваться») или же, оставляя эти «словечки» в косвенной конструкции, заключить их все же в кавычки (Волошинов 1929: 152).

По мнению В. М. Алпатова, обстоятельно исследовавшего книгу «Марксизм и философия языка», «и русская косвенная речь имеет свои особенности, которые нельзя сводить к чисто грамматическим (именно за это критикуется А. М. Пешковский, игнорировавший стилистику)» (АлПАтов 2005: 175).

Полемика М. М. Бахтина с А. М. Пешковским продолжилась заочно и позднее, в 1940-1950-е гг. Так, в статье «Вопросы стилистики на уроках русского языка» (1945) развивается та же мысль, что и в монографии 1929 г.:

Грамматические формы нельзя изучать без постоянного учета их стилистического [курсив - О. Н.] значения. Грамматика, оторванная от смысловой и стилистической стороны речи, неизбежно вырождается в схоластику (БАХтин 1996: 141).

В этой фразе, которой открывается упомянутая работа, звучит скрытый упрек формалистам Московской лингвистической школы. Здесь М. М. Бахтин рассматривает данный тезис на примере формы бессоюзного сложного предложения. И хотя автор отмечает «ценные наблюдения» Потебни, Шахматова и Пешковского, в итоге он склоняется к мысли о том, что «вопрос этот не был освещен в нашей литературе» (БАХтин 1996: 144). В. М. Алпатов уместно замечает:

...перефразирование предложения, сохраняя некоторое его содержание, резко меняет его стилистически; варианты такого рода далеко не синонимичны, что не учитывал «формалист» Пешковский (АлпАтов 2005: 297).

В статьях и дневниковых записях содержатся интересные замечания М. М. Бахтина в связи с идеями А. М. Пешковского, их критикой В. В. Виноградовым и др. Приведем только два фрагмента из архивных записей к работе «Проблема речевых жанров»:

«Коммуникация» Пешковского. Интонация сообщения (обращенность, адресованная интонация). Она принадлежит лишь целому высказывания [так! - О. Н.], а предложению[,] лишь взятому вне контекста и фигурирующему как целое»; «Понятие речевого целого у Пешковского. Это речевое целое, ощущаемое как единое и в основном интонационное, ничего не имеет общего с речевыми жанрами (высказываниями) (БАХтин 1996: 244, 245).

Мы видим, что формалистические и в целом языковедческие взгляды А. М. Пешковского, высказанные наиболее четко в «Русском синтаксисе...», обсуждались много и в разных ракурсах, находили преломление в традиционной и частной грамматике, стилистике, поэтике, философских аспектах науки, т. е. в той или иной мере способствовали усилению внимания к проблемам лингвистики текста, его речевого восприятия и в конечном итоге решали спорные методические и теоретическое вопросы. 
Отметим особенности этой и, пожалуй, других работ А. М. Пешковского, если оценивать их как документы эпохи - сохранение богатого лингвистического опыта прошлого, чуткая ориентация в преобразованиях первых десятилетий XX века, что всегда у него сопровождалось тончайшей интуицией и чувством языкового динамизма, выводящими концепцию ученого на новый уровень. А. В. Бондарко в этой связи писал:

[...] А. М. Пешковский фактически ставит вопрос о тех единствах, которые исследуются в современной лингвистической литературе с использованием таких терминов, как понятийная категория, функционально-семантическая категория, функционально-семантическое поле... (БондАРко 1978: 22),

т. е. о том, что в настоящее время называют языковой картиной мира.

Мы не будем здесь более подробно обсуждать достоинства и недостатки классического труда А. М. Пешковского и сопровождавшую его лингвистическую дискуссию (см. БЕРнштЕЙн 1938, БЕЛОв 1958), а также анализировать другие исследования в этом направлении, продолжившие традицию «Русского синтаксиса...» (см. литературу: БулАхов 1978: 133-135), но хотим заметить, что свои опыты в области стилистики и поэтики он неизменно подкреплял грамматическими наблюдениями и в этом смысле всегда старался проникнуть в сущность языка - СЛОВО.

\section{7. А. М. Пешковский - лексикограф}

Отдельная сторона творчества - это работа А. М. Пешковского по созданию первого лексикографического проекта советской эпохи: толкового словаря русского литературного языка (так называемого «Ленинского словаря»), которая проводилась в начале 1920-х гг. Здесь, казалось бы, в не характерной для ученого области, его талант и удивительное языковое чутье снова пригодились. Нами обнаружены свидетельства самого непосредственного участия А. М. Пешковского в подготовительной работе. Так, он занимался отбором лексики для будущего словаря и был буквенным редактором, собственноручно составлял картотеку, причем для анализа взял столь же неожиданного для советской действительности тех лет автора - А. М. Ремизова (Архив РАН. Ф. 502. Оп. 3. Ед. хр. № 96. Л. 17), выступал в дискуссиях по отдельным проблемам.

Приведем пример одной из них. В октябре 1921 г., когда активно разрабатывался план словаря, Д. Н. Ушаков записал в своем дневнике:

Стоян. Иное значение. Значения не определен $<$ ия $>$ [...]. Род только от слов на $b$ [...]. Косв $<$ енные $>$ п<адежи $>$ в особых случаях. Им $<$ енительный $>$ мн $<$ ожественного $>-$ в случае паралл<ельности> (Архив РАН. Ф. 502. Оп. 3. Ед. хр. № 97. Л. 14).

И далее:

Искать словари Стояна (Архив РАН. Ф. 502. Оп. 3. Ед. хр. № 97. Л. 14 об.). 
Речь шла об известном в то время лексикографе П. Е. Стояне и его трудах, составленных «по образцу Даля и Ляруса» (Стоян 1916). А. М. Пешковский предложил «отказаться от Стояна»: «для улучшения Словаря» и «для сохранения времени» (Стоян 1916: 15). Он выдвинул следующие аргументы (в записи Д. Н. Ушакова):

I. Стоян - не рамки совр $<$ еменного $>\pi<$ $>$ т $<$ ератур $>$ H $<$ ого $>$ яз $<$ ык $>\mathrm{a}$

1. Пропадет соврем<енная > $<$ итерату $>$ ра $[\ldots]$

2. Слова из Стояна - будут плохо определены

II. Невыгодно

Выписка - больше времени, чем без Стояна [...]

Производных слов Стоян не выписывает [...]

Неудовлетворительность объяснения (сужение значения, отсутствие определения формальных слов) -

Редакционная работа сокращается

Выборщику даны бо́льшие полномочия, чем следует

Понижается оплата труда $3 \mathrm{~T}<$ ысячи $>-9 \mathrm{~T}<$ ысяч $>$ в час

Усложняется инструкция

Эволюция - не от книжности к живости, а просто [...]

(Архив РАН. Ф. 502. Оп. 3. Ед. хр. № 97. Л. 15-15 об.).

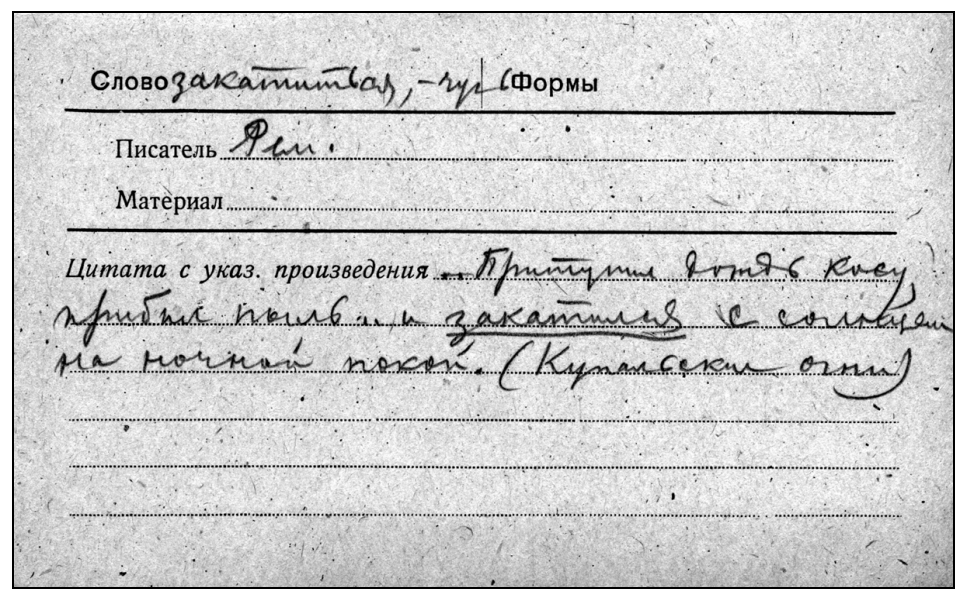

Автограф А. М. Пешковского на карточке проекта «Толкового словаря русского литературного языка» (1921-1922 гг.). Из домашнего архива О. В. Никитина.

Итогом октябрьского обсуждения стала записка, сделанная Д. Н. Ушаковым, с характерным заголовком следующего содержания:

\section{О столпе}

Мне кажется, что я предлагаю то, что все мы думаем, но что для меня окончательно формулируется тем обсуждением в связи с докладом Пешк<овско>го.

Если слово есть у Стояна, то в «обычном» значении его не выписывать. 
Справляться с значением не нужно. Всякое мало-мальски необычное или показавшееся таковым (ср. «сомнения» - в пользу выписки), выписывается, хотя бы оно было и у Стояна. Этим сохраняется выборщицкий материал для определения значений.

Остается вопрос об «обычном». А он всегда невидимо присутствует и решается априорно, субъективно. [...]

Вместо Стояна - другой (Архив РАН. Ф. 502. Оп. 3. Ед. хр. № 97. Л. 16 об.).

Словарь так и не был издан (см. Никитин 2004, Никитин 2012), а работа по его подготовке была приостановлена, но этот опыт сотрудничества с виднейшими филологами того времени (Д. Н. Ушаковым, П. Н. Сакулиным, А. Е. Грузинским, Н. Н. Дурново, Р. О. Шор, А. М. Селищевым и др.) пригодился А. М. Пешковскому.

Спустя несколько лет, в 1925 г., он подготовил для «Литературной энциклопедии» интереснейшие статьи по грамматике и стилистике, ставшие продолжением работы ученого в области лексикографической теории и практики (см. ПЕшкОвский 2007: 409-437).

\section{8. Полемика Л. Тимофеева с А. М. Пешковским}

А. М. Пешковский внес весомый вклад и в другую отрасль филологии стилистику, поэтику, в изучение языка художественной литературы. Публикаций на эти темы совсем немного, но они очень выразительны и показывают особое видение художественного полотна глазами тонкого ученого, сумевшего и здесь найти свой подход к анализу текста. Это почти забытые ныне статьи: «Десять тысяч звуков. Опыт звуковой характеристики русского языка как основы для эвфонических исследований» (ПЕшковский 1925b), «Стихи и проза с лингвистической точки зрения» (ПЕшковский 1925c), «Принципы и приемы стилистического анализа и оценки художественной прозы» (ПЕшковский 1927), «Ритмика „Стихотворений в прозе“ Тургенева» (ПЕшковский 1928). Все они переизданы нами в «Избранных трудах» (ПЕшковский 2007: 439-535) и частично были опубликованы самим ученым (ПЕшковский 1925a).

Художественный талант А. М. Пешковского проявился не только в своеобразном подходе к рассмотрению текста, но и в его интерпретации (он, подобно символистам, свободно оперировал такими понятиями, как благоритмика, звуковая символика, мелодика, рассуждал о соотношении ритма и содержания, говорил о звуковых повторах и т. д.). При этом А. М. Пешковский применял и методы математической лингвистики, и структурного анализа текста и в то же время балансировал на грани традиционной филологической практики поуровневого рассмотрения языковых единиц. Названные статьи это и эксперимент, к которому он шел сознательно, как бы пробуя свое мастерство, нащупывая нити словесного тайноречия. Ему удавались одинаково легко и проза, и поэзия, а в анализе текстов он не пользовался шаблонами, постепенно отступая от нормативного взгляда на словесный знак, но (вот парадокс!) находясь в русле грамматической эстетики своего времени. 
Один из критиков А. М. Пешковского, Л. Тимофеев, анализируя подход ученого к изучению словесного художественного полотна, даже назвал его «новой теорией ритма прозы». «Несомненно, что эта теория, - писал он в рецензии, - представляется наиболее интересной попыткой определить, наконец, что же такое ритм прозы, как он строится и как его анализировать...» (ТимофеЕв 1928: 21). Несмотря на признание оригинальности замысла ученого - разрешить вопрос о ритмическом строении художественной прозы, А. М. Пешковский, по мнению Л. Тимофеева, «грозит направить доверившегося ей [теории - О. Н.] исследователя на опасный путь»:

...он видит основную разницу между ритмом стиха и ритмом прозы в том, что их движение создается чередованием различных речевых единиц: из ряда речевых единиц [1) Слог. 2) Такт (об'единение слабых безударных слогов вокруг сильнейшего, ударного). 3) Фонетическое предложение (об'единение ударений-тактов вокруг сильнейшего, фразного ударения). 4) Интонационное целое (иначе - фонетический период; об'единение фонетических предложений вокруг сильнейшего] стих как единицей оперирует слогом, а проза тактом (ТимОФЕЕВ 1928: 21).

Л. Тимофеев полагал, что в изучении ритмического строения прозы А. М. Пешковский исходил из «чисто лингвистических предпосылок».

Но именно тогда, когда теория переносится на конкретную почву анализа реального речевого материала, когда ставится вопрос об обнаружении основных ритмических единиц прозы, самое существование этих единиц (не лингвистически, конечно, а ритмически) начинает представляться несколько сомнительным (ТимоФЕев 1928: 22).

В чем же, по мнению Л. Тимофеева, заключалась основная проблема?

Прежде всего возникает вопрос о ритмической значимости большой единицы прозаического ритма - интонационного целого, которое по своей роли (по проф. Пешковскому) соответствует стихотворной строфе: ведь дело в том, что любой речевой элемент (в данном случае - интонационное целое) может иметь ритмическое значение только при том условии, если он находится в ряду подобных ему величин и тем самым ощущается как единица этого ряда. Этому условию целиком отвечает строфа как определенное сочетание стихотворных форм, повторяющееся на протяжении всего произведения (например, 14-строчная строфа «Евгения Онегина»); в этом случае она действительно является закономерно повторяющейся единицей, т. е. элементом ритма. Это же необходимое условие иеликом отсутствует [курсив - О. Н.] в применении к тем интонационным целым, которые призваны исполнять роль «строф» в прозе (ТимОФЕЕВ 1928: 22).

Итак, полемика Л. Тимофеева с А. М. Пешковским развивается вокруг «чисто лингвистических» и ритмических единиц прозы, с другой стороны (и эта позиция критика представляется более зрелой, чем взгляд экспериментатора А. М. Пешковского) - делается акцент на недопустимости «отыскивания в прозе единиц стихового ритма („стоп“ и т. п.) именно потому, что за 
отсутствием соответствующего ряда они перестают быть единицами [курсив - О. Н.] и не создают уже ритмического движения...» (ТимоФеЕв 1928: 23). Следовательно, по мнению Л. Тимофеева, интонационное целое нельзя принять за «большую ритмическую единицу прозы, аналогичную стихотворной строфе», «и мы... остаемся уже только с двумя ритмическими единицами прозы: тактом и фонетическим предложением (как об'единением тактов)» (ТимОФЕЕВ 1928: 23). Но и здесь у критика тоже возникают сомнения:

По отношению к фонетическому предложению (т. е. к более крупной единице) неясность состоит, прежде всего, в том, что, как говорит и сам проф. Пешковский («Русская речь», 72), самое деление письменной речи на фонетические предложения лишено твердых, абсолютно об’ективных опорных пунктов (ТиМОФЕЕВ 1928: 23).

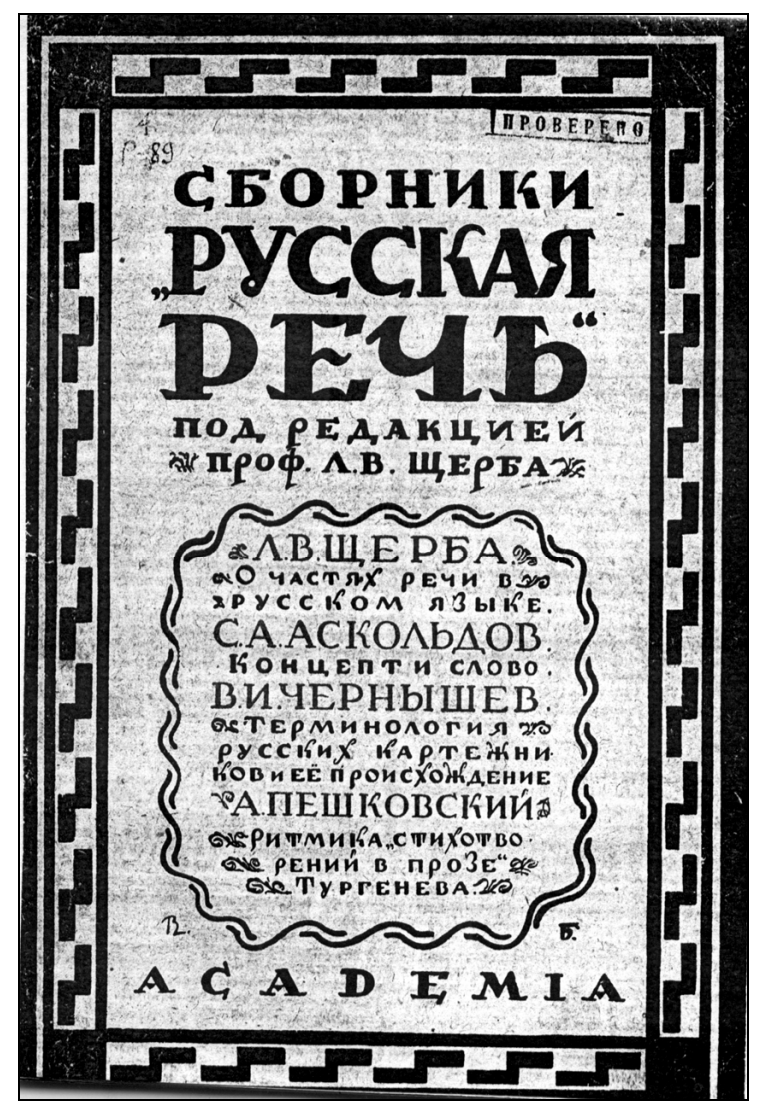

Еще один фрагмент в объемной статье-рецензии Л. Тимофеева интересен для освещения полемических настроений в этой, еще более уязвимой, чем грамматика, с точки зрения теоретических построений области. Остается дискуссионным также и вопрос самой «системы членения прозы на единицы», как ее представлял А. М. Пешковский: 
...не привносит ли он, при своей интерпретации ритма прозы такого в нее момента, который ему не дан об'ективно речевым материалом, не учитывает ли он такого элемента в прозе, который или совсем не дан, или дан в очень слабой степени? (ТимОФЕев 1928: 24).

В этой интересной и богатой фактами и размышлениями рецензии есть и другие моменты, так и или иначе включенные в дискуссию о «теории ритма прозы» А. М. Пешковского: соотношение прагматической (нехудожественной) речи и литературной, выяснение признаков стихового и прозаического ритма и др. Все это свидетельствует об оригинальности взглядов ученого, показывает его увлеченность данной проблематикой и стремление найти ключ к системному анализу художественного мира слова.

В данном направлении, несомненно, на А. М. Пешковского оказал влияние М. А. Волошин, с которым он постоянно обменивался мнениями и дискутировал (их объемная переписка до сих пор издана не полностью; об этом см. Никитин 2017a, Никитин 2017b, Никитин 2017с и личный фонд М. А. Волошина № 562 в Рукописном отделе Института русской литературы РАН в Санкт-Петербурге). Как можно заметить, указанные работы вышли частью в сборниках статей ученого, а также в получивших большой резонанс в филологическом мире трудах литературной секции Государственной академии художественных наук «Ars poetica I» (1927), альманахе «Свиток» (1925) и книгах Государственного института истории искусств «Русская речь» (1928). Там же публиковались статьи Л. В. Щербы, В. В. Виноградова, Л. П. Якубинского, С. А. Аскольдова, В. И. Чернышева, Б. А. Ларина и других ученых. Таким образом, А. М. Пешковский в своем творческом полете оказался в ином «концептуальном» пространстве и так же естественно проявился в разноликой художественной среде, где он был полноправным участником живого эксперимента, придавшего отечественной филологической традиции тех лет иной пафос.

Итак, 1920-е гг. были самым продуктивным периодом в научной деятельности ученого. Он смог реализовать многие свои идеи, которые (и это главное) нашли практическое применение в школе и вузе и остались в памяти как «сокровищницы тончайших наблюдений над русским языком» - так выразился Л. В. Щерба о книге А. М. Пешковского «Русский синтаксис...» (ЩЕРБА 1928: 5). Эти же слова можно с уверенностью отнести и к остальным методическим и лингвостилистическим экспериментам А. М. Пешковского.

\section{9. Последние труды А. М. Пешковского}

К 1930-м гг. относится очень немного работ А. М. Пешковского, но и они показательны. Так, в 1931 г. в Праге вышла статья ученого «Научные достижения русской учебной литературы в области общих вопросов синтаксиса». Она была опубликована в материалах съезда славянских филологов, состоявшегося в Праге в 1929 г. В ней автор произвел анализ учебной литературы, 
представленной такими именами, как В. Гиппиус, П. А. Дудель, Н. Н. Дурново, С. О. Карцевский, М. Н. Петерсон, Д. Н. Ушаков и др. Самым основным достижением рассмотренных книг он считал

настойчивое проведение... определенного взгляда на самую природу грамматической формы. Взгляд этот сводится к тому, что природа эта двоякая, внешняя и внутренняя, и что всякая форма помещается, так сказать, на стыке своей внешней и внутренней стороны (ПЕшковский 1931: 3).

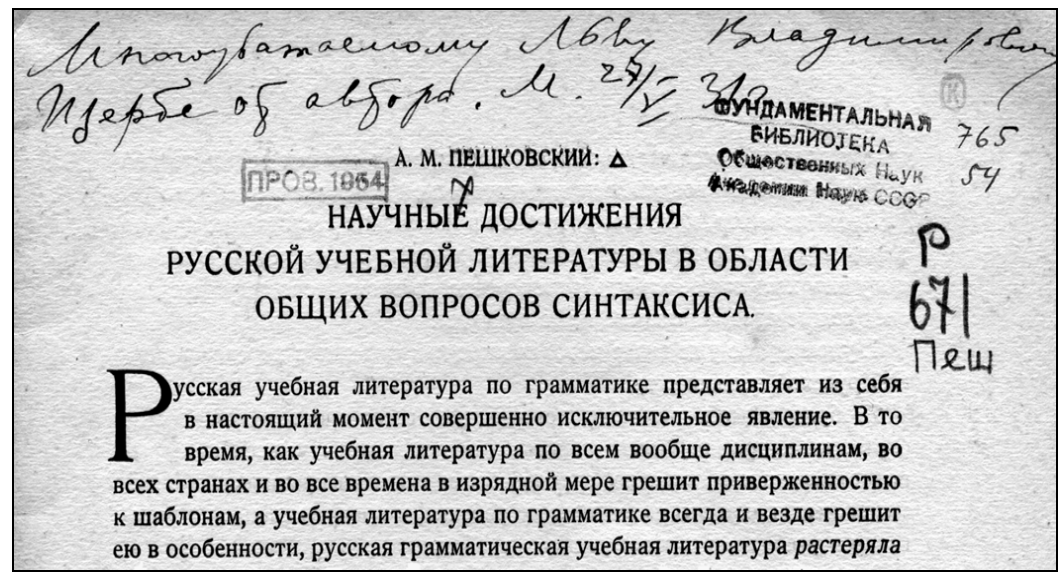

Оттиск статьи А. М. Пешковского (фрагмент) с дарственной надписью Л. В. Щербе

В данном высказывании ученого проявлялось не механическое сцепление грамматических фактов, а желание рассмотреть за оболочкой формы ее ядро. Ученый рассуждал далее так:

Нельзя сказать, чтобы с пониманием термина «форма» в науке все обстояло благополучно. Трудность определения некоторых формальных значений, частые и зияющие противоречия между формальным смыслом слова или словосочетания и реальным, наконец многозначность огромного большинства форм...- все это приводит к тому, что «форма» нередко прямо противопоставляется «смыслу», «идее», т. е. понимается или, по крайней мере, изображается как нечто чисто внешнее, звуковое. С теоретической точки зрения это, конечно, явно несостоятельно, так как совершенно непонятно, как можно было бы различить в языке ту или иную форму именно как форму (а не как фонему или сочетание фонем), если бы у нее не было никаких внутренних признаков (ПЕшковский 1931: 3).

В этой статье содержится и другой важный тезис. А. М. Пешковский утверждал:

...ученые... не могут в настоящее время ограничиться знакомством с соответствующими научными русскими трудами, а должны быть основательно знакомы и с русской учебной литературой (ПЕшковский 1931: 22). 
В 1930 г. переиздается сборник статей «Вопросы методики родного языка, лингвистики и стилистики», вновь отредактированных А. М. Пешковским (см. Пешковский 1930). В эти же годы появились работы «Реформа или урегулирование» (1930), «Новые принципы в пунктуации» (1930), «О терминах „методология“ и „методика“ в новейшей методической литературе» (1931) и посмертно «О грамматическом разборе» (1934) и др. (см. библиографию: ПЕшковский 2007: 799-800).

Как можно заметить даже по перечню последних трудов А. М. Пешковского, его продолжали интересовать очень разные, часто спорные проблемы, находящиеся на стыке лингвистики и методики преподавания языка. Все они имеют большое практическое значение. В то же время ученый выдвинул несколько ценных теоретических идей (разработка понятия о формальной категории слов и их связи в словосочетаниях; определение основных синтаксических конструкций; постановка задачи функционирования литературной речи; изучение звукозначений и их взаимных соотношений; выявление роли интонации в формировании синтаксической структуры предложения; разработка методологии лингвистических экспериментов и др.), получивших развитие в последующие десятилетия. Не оставлял он без внимания вопросы поэтики и стилистики.

\section{0. Заключение}

Таким образом, лингвистические идеи ученого при всей их привязанности, по большей части, только к одному уровню грамматических исследований на самом деле далеко выходят за пределы сугубо синтаксических рассуждений А. М. Пешковского и обращают предмет его интереса на более широкий диапазон языкотворчества - психологию и социологию лингвистики в целом, семантическое пространство языка, поэтику, культуру филологического строительства. Современные лингвисты справедливо называют А. М. Пешковского новатором: «в частности, он считал важным постановку лингвистом экспериментов над собой с помощью интроспекции» (АлПАТов 2001: 232). Р. А. Будагов посвятил ему отдельную главу «А. М. Пешковский и постановка эксперимента в языкознании» (БудАгов 1988: 153-176).

А. М. Пешковского нельзя отделить от философии и эстетики того времени, но, как страстный поэт, он постоянно искал, рождал и провозглашал новые грани в «человеческом измерении» языка, не укладывался в заполненные традиционными схемами «технологии» научной работы. Одним из первых в отечественной лингвистике А. М. Пешковский аргументированно применил метод статистического анализа, арифметической «инструментовки» для выявления звуковых пропорций литературной речи. Везде предельно конкретно, с математической точностью и только ему свойственным особым психологическим видением языка он старался проникнуть в самую суть изучаемого явления, показать его в движении, с разных сторон, соединяя под- 
час ветви словесного древа в симфонию текста. Каждая работа ученого в той или иной мере показывала механизмы решения спорной научной задачи, пути возможного прорыва в исследовании знака - текста - системы. Одним из них стал сознательный эксперимент: фонетический, грамматический, стилистический, структуральный.

Перефразируя некогда высказанное И. И. Срезневским об А. А. Потебне мнение, можно с уверенностью сейчас его отнести и к А. М. Пешковскому:

Не он начал то, за что взялся; но он продолжал начатое другими с таким успехом, что если теперь кто-нибудь займется изучением русского языка... и не возьмет в помощь себе [трудов А. М. Пешковского - О. Н.], то он во многих случаях останется в темноте, с вопросами без ответов или с неясными ответами без доказательств (подлинную цитату см. СРЕзНЕВский 1977: 324).

Подвигом всей своей деятельности Александр Матвеевич Пешковский показал ориентиры в науке не скупым языком терминов и надуманными концепциями, а непосредственным экспериментом и гениальной интуицией словесного «материалиста», не мыслившего себя без творчества. Именно оно как наивысшая степень интеллектуально-духовного прозрения способствовало самовыражению А. М. Пешковского. Этот завет он оставил потомкам. Среди них были и поэты - его ученики. Один из литераторов, В. Г. Шершеневич, посвятил А. М. Пешковскому раздел «Ломать грамматику» в своей книге « 2 х $2=5$. Листы имажиниста» (ШеРШЕНЕВич 1920). В этом художественно-лингвистическом порыве есть что-то символическое. Значит, филологические эксперименты А. М. Пешковского будут вдохновлять нас и впредь на новые открытия.

\section{Источники}

ОР ИРЛИ = Отдел рукописей Института русской литературы (Пушкинский Дом) (Санкт-Петербург).

Архив РАН = Архив Российской академии наук (Москва).

\section{Литература}

АБАКумов 1947 = АБАкумов С. И. Работы советских руссистов [sic!] за 30 лет. Pусский язык в школе 1947/5: 9-19.

АлПАТОВ 2001 = АлПАТОВ В. М. История лингвистических учений. Изд. 3-е, испр. и доп. Москва, 2001.

АлПАтов 2004 = АлПАтов В. М. История одного мифа. Марр и марризм. Изд. 2-е, доп. Москва, 2004.

АлПАТов 2005 = АлПАТов В. М. Волочинов, Бахтин и лингвистика. Москва, 2005.

АПРЕСЯН 2001 = АПРЕСЯН Ю. Д. «Русский синтаксис в научном освещении» В контексте современной лингвистики. В кн.: ПЕшковский А. М. Русский синтаксис в научном освещении. Изд. 8-е, доп. Москва, 2001. III-XXXIII. 
БАЗИЛЕВИч 1947 = БАЗИЛЕВИЧ Л. И. Русский язык как предмет преподавания в советской средней школе (1917-1947). Русский язык в школе 1947/5: 20-35.

БАХТИн 1996 = БАХТИн М. М. Собрание сочинений. Т. 5. Работы 1940-х-нач. 1960-х годов. Москва, 1996.

БАХТИН 2000 = БАХТИн М. М. Фрейдизм. Формальный метод в литературоведении. Марксизм и философия языка. Статьи. Москва, 2000.

БЕЛов $1958=$ БЕЛОВ А. И. А. М. Пешковский как лингвист и методист. Москва, 1958. БЕРНШТЕЙН 1938 = БЕРНШТЕЙН С. И. ОсновнЫе ПОНЯТИя грамМатиКИ в освещениИ А. М. Пешковского. В кн.: ПЕшковский А. М. Русский синтаксис в научном освещеении. Изд. 6-е. Москва, 1938. 7-42.

БОНДАРКО 1978 = БОНДАРКО А. В. Грамматическое значение и смысл. Ленинград, 1978.

БУДАГОВ 1988 = БУдАГОВ Р. А. Портреты языковедов XIX-XX вв. Из истории грамматических учений. Москва, 1988.

БуддЕ 1914 = БуддЕ Е. Ф. [рец. на:] Пешковский А. М. Русский синтаксис в научном освещении. Популярный очерк. Пособие для самообразования и школы. Москва, 1914. Журнал Министерства народного просвещзения 1914/12: 342-355.

БУЛАхов 1978 = БулАХов М. Г. Восточнославянские языковеды. Биобиблиографический словарь. Т. З. Минск, 1978.

ВИНОГРАДОВ 1938 = ВИНОГРАДОВ В. В. Современный русский язык. ВыП. 1. Введение в грамматическое учение о слове. Москва, 1938.

ВИНОГРАДОВ 1947 = ВИНОГРАДОВ В. В. Русский язык. Грамматическое учение о слове. Москва-Ленинград, 1947.

Волошинов 1929 = Волошинов В. Н. Марксизм и философия языка. Основные проблемы сочиологического метода в науке о языке. Ленинград, 1929.

Золотов 1932 = Золотов Н. Я. Против буржуазной контрабанды в языкознании. В кн.: Против буржуазной контрабанды в языкознании. Сборник бригады Института языка и мышления Академии наук СССР. Ленинград, 1932. 7-27.

Клоьуков 2001 = КлоБуков Е. В. «Русский синтаксис в научном освещении» А. М. Пешковского (о непреходящей актуальности грамматической классики). В кн.: ПЕшковский А. М. Русский синтаксис в научном освещении. Изд. 8-е. Москва, 2001. 3-19.

Лоя $1930=$ Лоя Я. В. За марксистское языковедение. Русский язык в советской школе 1930/5: 54-56.

Никитин 2004 = Никитин О. В. Из истории советской лексикографии 1920-х гг. Русский «Лярусс» и его создатели. Scando-Slavica 50 (2004): 23-46.

Никитин 2006 = Никитин О. В. Александр Матвеевич Пешковский. Московский журнал. История государства Российского 2006/1: 20-28.

Никитин 2012 = Никитин О. В. Очерки по истории русской лексикографии первой половины XX века (толковые словари). Славянск-на-Кубани, 2012.

Никитин $2017 \mathrm{a}=$ Никитин О. В. «Жизнеописание Пешковского в юности. Тема очень благодарная...». Опыт воссоздания портрета известного ученого. Вестник Вологодского государственного университета 2017/1: 89-96.

Никитин $2017 \mathrm{~b}=$ Никитин О. В. «...решил бесповоротно идти на филологический». Дискуссии и споры М. А. Волошина с А. М. Пешковским в контексте исторических событий 1900-х гг. Вестник Вологодского государственного университета 2017/2: 87-93.

Никитин 2017c = Никитин О. В. Лики творчества А. М. Пешковского: 1910-1930-е гг. Вестник Вологодского государственного университета 2017/3: 68-73. 
ПЕТРОВА 1932 = ПЕтРОВА Е. Н. Методологическое лицо журнала «Русский язык в советской школе». Против буржуазной контрабанды в языкознании. Сборник бригады Института языка и мышления Академии наук СССР. Ленинград, 1932. 153 161.

ПетровА 1936 = Петрова Е. Н. Грамматика в средней иколе. Методические очерки. Москва -Ленинград, 1936.

ПЕшковский 1914 = ПЕшковский А. М. Русский синтаксис в научном освещении. Пособие для самообразования и иколь. Москва, 1914.

ПЕшковский 1918 = ПЕшковский А. М. Школьная и научная грамматика. Oпыт применения научно-грамматических принщипов к икольной грамматике. Изд. 2-е, испр. и доп. Москва, 1918.

ПЕшковский 1925a = ПЕшковский А. М. Сборник статей. Методика родного языка, лингвистика, стилистика, поэтика. Ленинград-Москва, 1925.

ПЕшковский $1925 \mathrm{~b}=$ ПЕшковский А. М. Десять тысяч звуков. Опыт звуковой характеристики русского языка как основы для эвфонических исследований. В кн.: ПЕшковский А. М. Сборник статей. Методика родного языка, лингвистика, стилистика, поэтика. Ленинград-Москва, 1925. 167-191.

ПЕшковский 1925c = ПЕшковский А. М. Стихи и проза с лингвистической точки зрения. В кн.: ПЕшковский А. М. Сборник статей. Методика родного языка, лингвистика, стилистика, поэтика. Ленинград-Москва, 1925. 153-166. [Первоначально: Альбом «Свиток», 1925, № 3.]

ПЕшковский 1927 = ПЕшковский А. М. Принципы и приемы стилистического анализа и оценки художественной прозы. В кн.: Петровский М. А. (ред.) Ars poetica I. Сборник статей Б. И. Ярхо, А. М. Пешковского, М. А. Петровского, М. П. Столярова, Р. О. Шор. Труды Государственной академии художественных наук. Литературная секция. Москва, 1927. 29-68.

ПЕшковский 1928 = ПЕшковский А. М. Ритмика «Стихотворений в прозе» Тургенева. В кн.: ЩЕРБА Л. В. (ред.) Сборники «Русская речь», издаваемые Отделом словесных искусств. Новая серия II. Ленинград, 1928. 69-83.

ПЕшковский 1930 = ПЕшковский А. М. Вопросы методики родного языка, лингвистики и стилистики. Москва-Ленинград, 1930.

ПЕшковский $1931=$ ПЕшковский А. М. Научные достижения русской учебной литературы в области общих вопросов синтаксиса. Zvláštni otisk ze sborniku praci v Sjezdu slovanských filologú v Praze, 1929. Sv. II. Praha, 1931.

ПЕшковский 1938 = ПЕшковский А. М. Русский синтаксис в научном освещении. Изд. 6-е. Москва, 1938.

ПЕшковский 1956 = ПЕшковский А. М. Русский синтаксис в научном освещении. Изд. 7-е. Москва, 1956.

ПЕшковский 2007 = ПЕшковский А. М. Лингвистика. Поэтика. Стилистика. Избранныле трудыл. Сост. и науч. ред. О. В. Никитин. Москва, 2007.

Родной язык 1928 = Родной язык и литература в трудовой школе 1928/3: 120-121.

СРЕЗНЕВСКИй 1977 = СРеЗНЕВСКИй И. И. Записка о трудах профессора А. А. Потебни, представленная во 2-е Отделение Академии наук. В кн.: ПотЕБня А. А. Из записок по русской грамматике. T. IV. Вып. II. Москва, 1977. 305-324.

Стоян 1916 = Стоян П. Е. Мальий толковый словарь русского языка. Изд. 3-е. Петроград, 1916.

ТимОФЕеВ 1928 = ТимОфеЕВ Л. Ритм стиха и ритм прозЫ. О новой теории ритма прозы проф. А. М. Пешковского). На литературном посту 1928/19: 20-30. 
УшАКов 1915 = УшАков Д. Н. (рец. на:) Пешковский А. М. Русский синтаксис в научном освещении... Москва, 1914; Пешковский А. М. Школьная и научная грамматика... Москва, 1914. Русские ведомости 1914/91: 6.

УшАКОВ 1995 = УшАКОВ Д. Н. Русский язык. Учебное пособие для студентов педагогических университетов и институтов по специальности «Русский язык и литература». Москва, 1995.

Филин 1932 = Филин Ф. П. Борьба за марксистско-ленинское языковедение и группа «Языкфронт». В кн.: Против буржуазной контрабанды в языкознании. Сборник бригады Института языка и мышления Академии наук СССР. Ленинград, 1932. 28-46.

ЧЕМОДАНОВ 1947 = ЧЕМОДАНОВ Н. С. Советское языкознание. Русский язык в школе 1947/5: 3-8.

ШАПИРО 1956 = ШАПиРО А. Б. А. М. Пешковский и его «Русский синтаксис в научном освещении». В кн.: Пешковский А. М. Русский синтаксис в научном освещении. Изд. 7-е. Москва, 1956. 3-6.

ШЕРШЕНЕВИЧ 1920 = ШЕРШЕНЕВИЧ В. 2 2 2 = 5. Листы имажиниста. Москва, 1920.

ЩЕРБА 1928 = ЩЕРБА Л. В. О частях речи в русском языке. В кН.: ЩЕРБА Л. В. (ред.) Сборники «Русская речь», издаваемые Отделом словесных искусств. Новая серия II. Ленинград, 1928. 5-27.

\author{
OLEG VIKTOROVICH NIKITIN \\ Moscow Region State University (Mytishchi)
}

\title{
Notes to the Linguistic Portrait of A. M. Peshkovsky in the Context of Scientific Debates of his Time
}

This paper reveals little-known episodes from A. Peshkovsky's scientific biography and analyses some fragments of his books and articles in the 1920s and 1930s that became the focus of linguistic discussions and showed ambiguous ideological situation in the science of that time. Special attention is paid to the formation of A. Peshkovsky as a linguist and methodist. His first works on "school and scientific grammar" that laid the foundations of the modern approach to the study of the theory and practice of syntax are analysed.

It is noted that the studies by A. Peshkovsky teetered at the level of implementing the ideas of the old Moscow linguistic school of academicians Fortunatov and Shakhmatov, while gravitating toward the insight of A. Potebnya and yet showing at the same time a different way of understanding grammatical ideas. The author claims that A. Peshkovsky went from the traditional diachronic analysis in the direction of the formal approach, while not abandoning "the psychological perception of the word". A. Peshkovsky, a reformer taking a stand in his search and linguistic experiments against the Marrist and tunnel-visioned understanding of the tasks of Soviet linguistics and methodological science, was subjected to unfair criticism for his stance.

The discussions that took place at that time testify to the consistency and scientific integrity of the scientist's views in the era of the struggle against "eclecticism", "formalism", and "incorrigible Indo-Europeanism". The paper presents some instances of correspondence disputes by V. Voloshinov and M. Bakhtin with A. Peshkovsky on the issues in relationship of grammar and stylistics. His opponents believed that "grammar detached from the 
semantic and stylistic side of speech inevitably degenerates into scholasticism". Drawing on materials from archives and personal collection, the author of this paper gives unique facts of the lexicographical activity of A. Peshkovsky in the early 1920s related to his work on the explanatory dictionary of the Russian literary language (not published).

The closing part of the paper analyses the dispute between L. Timofeev and A. Peshkovsky. It is stated that "the new theory of the rhythm of prose" by A. Peshkovsky and his works on psychophonetics caused an ambiguous reaction in the philological community and contributed to the activation of research seeking for a "system of division of prose into units" and other experiments on the study of literary texts. Consideration is also given to the works by A. Peshkovsky in the 1930s, in which the scientist solved new problems in the field of formal characteristics of words and word combinations, wrote about the functioning of literary speech as well as the role of intonation in the formation of the syntactic structure of the sentence. Emphasis is laid on the originality and experimental character of many theses by A. Peshkovsky further developed in the late 20 th and early 21 st centuries.

Keywords: Moscow linguistic school, formal grammar, linguistic experiment, syntax, stylistics, textology, linguistic personality, ideology, methodology of linguistics, scientific debates 